\title{
Genotyping of HBV and tracking of resistance mutations in treatment-naïve patients with chronic hepatitis B
}

This article was published in the following Dove Press journal:

Infection and Drug Resistance

5 July 2017

Number of times this article has been viewed

\author{
Sidelcina Rugieri Pacheco' \\ Maria Isabel Magalhães \\ Andrade dos Santos' \\ Andreas Stocker ${ }^{2}$ \\ Maria Alice Sant'Anna \\ Zarife ${ }^{3}$ \\ Maria Isabel Schinoni \\ Raymundo Paraná \\ Mitermayer Galvão dos \\ Reis' \\ Luciano Kalabric Silva' \\ 'Laboratory of Pathology and \\ Molecular Biology, Research Site \\ Gonçalo Muniz, Foundation Oswaldo \\ Cruz (CPqGM/Fiocruz-BA), ${ }^{2}$ Federal \\ University of Bahia, ${ }^{3}$ Central \\ Laboratory of Public Health of Bahia \\ (LACEN-BA), Salvador, Brazil
}

Correspondence: Sidelcina Rugieri Pacheco

Laboratório de Patologia e Biologia Molecular, Fundação Oswaldo Cruz, Centro de Pesquisa Gonçalo Moniz, I2I, Candeal, Salvador, Bahia CEP: 40296-7 I0, Brazil

Tel/fax +55 7l 31762254

Email srugieri@gmail.com
Background and aims: Resistance mutation analogs to nucleos $(\mathrm{t})$ ides have been described in treatment-naïve patients with chronic hepatitis B (CHB), with clinical implications. The aim of this study was to investigate primary resistance mutations and genotypes circulating in patients naïve to chronic hepatitis B, in the Northern and Northeastern regions of Brazil.

Methods: We conducted a study of resistance mutations and genotypic characterization of hepatitis B virus (HBV) in 189 treatment-naïve patients chronically infected with HBV.

Results: Drug resistance-associated mutations located in the RT domain of the P gene (rtHBV) were found in $6 \%$ of the treatment-naïve patients from the Northeastern Region. The mutations were rtA194T, rtL180M + rtM204V, rtS202I, rtM204I, and rtA181S. No patient in the Northern Region had the resistance mutation. In the gene $\mathrm{S}$ region, the frequency of vaccine escape mutations was $2.4 \%$ in the Northeastern Region and $8.6 \%$ in the Northern Region.

Conclusion: This information before the start of treatment may contribute to clinical decision making, reducing treatment failure and the risk of progression to cirrhosis and hepatocellular carcinoma for CHB.

Keywords: Northeast, North, Brazil, direct sequencing, treatment failure

\section{Introduction}

Although there is a safe and effective vaccine against hepatitis B virus (HBV) since the early 1980s, chronic hepatitis caused by this pathogen is far from being eradicated and continues to constitute a severe public health problem in many parts of the world, and was considered recently by the World Health Organization as a pandemic. There are 400 million people infected worldwide and, in Brazil, 2 million are chronically infected. Brazil has an ethnic, economic, and regional diversity that would be no different for the epidemiology of HBV infection, but also presents a very heterogeneous distribution. ${ }^{1-4}$ These individuals are exposed to the risk of developing severe complications including cirrhosis and hepatocellular carcinoma (HCC). ${ }^{5,6}$

In the last 20 years in Brazil, significant advances in the treatment for chronic hepatitis B (CHB) have occurred, initially with the use of interferon (IFN)-alpha, allowing to alter the natural progression of the disease. Currently, through the Clinical Protocol of Therapeutic Guidelines for Hepatitis B (2011), which directs the therapeutic conduct for HBV, five drugs are available for treatment, IFN-alpha and the nucleos(t)ide analogs (NAs) lamivudine (LAM), adefovir dipivoxil, entecavir (ETV), and tenofovir (TDF). ${ }^{6,7}$ However, the use of NAs for a long time can determine the emergence of strains resistant to the drug. 
The emergence of antiviral resistance has a close association with NA amino acid substitutions in the reverse transcriptase (RT region of the HBV genome), which are classified as primary and secondary self-compensatory resistance mutations. ${ }^{6,8}$ The NA therapy can induce certain resistance mutations, and it is noticed that natural HBV RT mutations exist even in treatment-naïve patients. ${ }^{9,10}$

In addition, the HBV genome is complicated and has been classified into eight genotypes (A-H) based on differences of $\geq 8 \%$ in its whole genome sequence. The HBV genotypes have distinct geographic distribution: genotype $\mathrm{A}$ has a universal distribution, being the predominant genotype in Europe, North and Central America, sub-Saharan Africa, and India. Genotypes $\mathrm{B}$ and $\mathrm{C}$ are predominant in Southeast Asia, China, Japan, and Australia. Genotype D is mainly found in the Middle East and the Mediterranean countries. Genotype E seems to be predominant in West Africa, whereas genotype $\mathrm{G}$ is distributed throughout the USA, Mexico, and France. Genotype F is mainly found in Central and South America and Alaska. Finally, genotype $\mathrm{H}$ is unique to Central America and the USA. ${ }^{11-13}$ Genotypes A, D, and F circulate among Brazilian HBV carriers. ${ }^{4}$

The aim of this study is to investigate primary resistance mutations in the genotypes circulating in patients naïve to CHB in the Northern and Northeastern regions, represented by the State of Acre and Bahia, and their implications in the clinical treatment of CHB.

\section{Methods}

\section{Patients}

A study of resistance mutations and genotypic characterization of HBV was conducted in 189 naïve patients chronically infected with HBV, 84 (Northeastern Region) and 105 (Northern Region), during the period of 2011-2015. All patients tested positive for the hepatitis B surface antigen (HBsAg) antigen within at least 6 months, and tested negative for HIV, and were naïve for the treatment of HBV, in two centers of reference for viral hepatitis, at the Northeastern Region, in the Hospital Universitário Professor Edgard Santos - HUPES and, at the Northern Region, in the Fundação Hospital do Acre - FUNDHACRE, Brazil. This study was reviewed and approved by the Ethics Committee of FUNDHACRE, Rio Branco, Acre, and the Ethics Committee of HUPES, Salvador, Bahia, Brazil. All participants provided written informed consent and the study followed the Declaration of Helsinki and Good Clinical Practice guidelines.

\section{HBV quantification}

HBV DNA was detected and quantified by the realtime polymerase chain reaction (PCR) assay. The test procedures followed the manufacturer's recommendations and were performed automatically at the laboratory facilities of the Public Health Central Laboratory (Laboratório Central de Saúde Pública) of the State of Acre and Bahia (LACEN).

\section{PCR}

The HBV DNA was extracted from $200 \mu \mathrm{L}$ of serum samples with High Pure Viral Nucleic Acid Kit (Roche, Basel, Switzerland) according to the manufacturer's instructions. The RT region of the $H B V$ gene $(1032 \mathrm{pb})$ was amplified by a nested PCR. Primers were described by Krekulova et al ${ }^{14}$ and modified to increase sensitivity to PCR. In the first reaction, the primers used were HB-1 $5^{\prime}$ TAT TTC CCT GCT GGT GGC TCC 3' (position 50-71) and HB-4 5' ACT TTC CAA TCA ATA GG 3' (position 969-986). In the second reaction, the primers used were HB-5 5' GAA CAG TAA ACC CTG CTC CG 3' (position 78-98) and HB-8 $5^{\prime}$ TGT ACA ATA TGA TCC TGT GG 3' ( position 909-929) (Thermo Fisher Scientific, Waltham, MA, USA).

For the amplification of DNA, $5.0 \mu \mathrm{L}$ of the sample was used for the first reaction and put into a mixture containing $2.5 \mu \mathrm{L} 10 \times$ PCR buffer, $0.5 \mu \mathrm{L}$ of deoxynucleotide triphosphate (dNTP) mix $(10 \mathrm{mM}), 1.25 \mu \mathrm{L}$ of $\mathrm{MgCl}_{2}(50 \mathrm{mM})$, $0.5 \mu \mathrm{L}$ of each primer, and $0.2 \mu \mathrm{L}$ of platinum Taq DNA polymerase $(5 \mathrm{U} / \mu \mathrm{L})$ (Thermo Fisher Scientific, Waltham, MA, USA), resulting in a final volume of $25 \mu \mathrm{L}$. The cycle conditions used initially were $94^{\circ} \mathrm{C}$ for 2 minutes for denaturing, followed by 45 cycles of $94^{\circ} \mathrm{C}$ for 30 seconds, $56^{\circ} \mathrm{C}$ for 30 seconds, $72^{\circ} \mathrm{C}$ for 2 minutes, and a final extension of $72^{\circ} \mathrm{C}$ for 7 minutes in a Mastercycler Gradient Thermal Cycler (Eppendorf, Hamburg, Germany).

The second reaction used $1.0 \mu \mathrm{L}$ of the PCR product, which was put into a mixture containing $5 \mu \mathrm{L} 10 \times$ PCR buffer, $1.0 \mu \mathrm{L}$ of dNTP mix (10 mM), $2.5 \mu \mathrm{L} \mathrm{MgCl}_{2}(50 \mathrm{mM})$, $5 \mu \mathrm{L}$ of each primer, and $0.2 \mu \mathrm{L}$ of platinum Taq DNA polymerase $(5 \mathrm{U} / \mu \mathrm{L})$, resulting in a final volume of $50 \mu \mathrm{L}$. The cycle conditions used initially were $94^{\circ} \mathrm{C}$ for 2 minutes for denaturing, followed by 35 cycles of $94^{\circ} \mathrm{C}$ for $30 \mathrm{sec}-$ onds, $60^{\circ} \mathrm{C}$ for 30 seconds, $72^{\circ} \mathrm{C}$ for 2 minutes, and a final extension of $72^{\circ} \mathrm{C}$ for 7 minutes in a Mastercycler Gradient Thermal Cycler. 


\section{Sequencing of the HBV RT region}

The samples were purified with a QIAquick PCR Purification Kit (Qiagen NV, Venlo, the Netherlands) and sequenced with forward and reverse primers using a BigDye Terminator 3.1 Cycle Sequencing kit (Thermo Fisher Scientific), according to the manufacturer's instructions. The reactions were performed in an automatic ABI PRISM 3100 Genetic Analyzer Sequencer (Thermo Fisher Scientific). The sequencing project coverage was only twofold to sixfold corresponding to the sequence obtained from each primer product (HB-2, HB-3, HB-5, HB-6, HB-7, and HB-8, data not shown).

\section{Sequence analysis}

To confirm the specificity of each amplicon, the sequences obtained were analyzed using the GenBank Basic Local Alignment Search Tool. Subsequently, sequences from the same patient were assembled to a reference sequence and conflicting sites were corrected by visual inspection (CLC Main Workbench v.5, Qiagen, Aarhus, Denmark). Consensus sequence of each HBV isolate was submitted to a web-based software for subtyping and prediction of phenotypic resistance to genotype-specific mutations in the polymerase gene (RT mutation) and escape mutation (HBs mutation) (Max-Planck-Institut für Informatik, Germany, at http://hbv.geno2pheno.org/index.php). One hundred and eighty-nine sequences of these analyses were submitted to the GenBank (accession number: KU847525-KU847634; KU847635-KU847735)

\section{Statistical analyses}

Statistical analyses were performed using the software SPSS 20.0 (IBM Corporation, Armonk, NY, USA). Comparison between groups was performed using a one-way analysis of variance $t$-test or a chi-square test, as appropriate. The HBV DNA concentrations were expressed on a logarithmic scale. A $P$-value of $<0.05$ was considered statistically significant.

\section{Results}

The samples from 189 treatment-naïve CHB patients were enrolled in this retrospective study. Their clinical features are summarized in Table 1 . There were 84 treatment-naïve patients at HUPES/Salvador-Bahia (Northeastern Region), consisting of $50.6 \%$ males and $49.4 \%$ females, with a median age of 44 years (the range was $18-72$ years). A high alanine aminotransferase (ALT) serum level (reference value is $>41 \mathrm{UI} / \mathrm{mL}$ ) was found in $38.7 \%$ of the patients, with a median of $45.65 \mathrm{UI} / \mathrm{mL}$. The HBV DNA level in the
Table I Clinical features of treatment-naïve patients for $\mathrm{CHB}$ attending two reference centers for viral hepatitis between $201 \mathrm{I}$ and 2015

\begin{tabular}{|c|c|c|c|c|}
\hline \multirow[t]{2}{*}{ Characteristics } & \multicolumn{2}{|c|}{ Northeast } & \multicolumn{2}{|l|}{ North } \\
\hline & $n=84$ & Percentage & $n=105$ & Percentage \\
\hline $\begin{array}{l}\text { Age* (min-max, } \\
\text { years) }\end{array}$ & $18-72$ & $44.3 \pm 12.3$ & $18-72$ & $40.5 \pm 12.3$ \\
\hline $\begin{array}{l}\text { Gender (male/ } \\
\text { female) }\end{array}$ & $40 / 39$ & $50.6 / 49.4$ & $39 / 66$ & $37.1 / 62.9$ \\
\hline $\mathrm{ALT}^{*}(\mathrm{IU} / \mathrm{L})$ & $7-231$ & $45.65 \pm 38.9$ & $|2-4| 4$ & $42.63 \pm 52.3$ \\
\hline $\mathrm{RV}>4 \mathrm{I} I \mathrm{IU} / \mathrm{L}$ & 29 & 38.7 & 28 & 28.3 \\
\hline $\mathrm{HBeAg}(+/-)$ & $10 / 62$ & |3.9/86.| & $07 / 91$ & $7.1 / 92.9$ \\
\hline HBV DNA log & 12 & 15.6 & 14 & 13.3 \\
\hline $10>4$ & & & & \\
\hline HBV DNA level* & I.5I-8.34 & $3.3 \pm 1.47$ & I.75-8.04 & $3.12 \pm 1.4$ \\
\hline HBV genotype & & & & \\
\hline$A$ & 75 & 89.3 & 62 & 59 \\
\hline$D$ & 2 & 2.4 & 22 & 21 \\
\hline $\mathrm{F}$ & 6 & 7.1 & 21 & 20 \\
\hline C & 1 & 1.2 & 0 & 0 \\
\hline Coinfection & & & & \\
\hline HBV HCV & 1 & 1.2 & 2 & 1.9 \\
\hline HBV HDV & & & 4 & 3.8 \\
\hline Mutation & & & & \\
\hline $\begin{array}{l}\text { Vaccine escape } \\
\text { (sHBV) }\end{array}$ & 2 & 2.4 & 9 & 8.6 \\
\hline $\begin{array}{l}\text { Mutation } \\
\text { resistance NA }\end{array}$ & 5 & 6 & 0 & 0 \\
\hline
\end{tabular}

Note: *Percentage column shown in median and SD and $\mathrm{n}$ column shown in min-max. Abbreviations: ALT, alanine aminotransferase; $\mathrm{HBeAg}$, hepatitis $B$ e antigen; $\mathrm{HBV}$, hepatitis B virus; HCV, hepatitis C virus; HDV, hepatitis D virus; NA, nucleoside/ nucleotide analogs; $\mathrm{RV}$, reference value; sHBV, surface antigen gene of hepatitis $B$ virus.

serum had a median of $\log 3.3$ (the range was $1.51-8.34$ ) while $86.1 \%$ of that was hepatitis B e antigen ( $\mathrm{HBeAg}$ ) sero-negative. The HBV genotype distribution found was: A (89.3\%), D (2.4\%), F (7.1\%), and C (1.2\%). Coinfection with hepatitis $\mathrm{C}$ virus (HCV) was found to be $1.2 \%$.

There were 105 treatment-naïve patients at FUNDHACRE/Rio Branco-Acre (Northern Region), consisting of $37.1 \%$ males and $62.9 \%$ females, with a median age of 40 years (the range was $18-72$ years). A high ALT serum level (reference value is $>41 \mathrm{UI} / \mathrm{mL}$ ) was found in $28.3 \%$ of the patients, with a median of $42.63 \mathrm{UI} / \mathrm{mL}$. The HBV DNA median load in serum was $3.12 \mathrm{log}$ copies $/ \mathrm{mL}$ (the range was 1.75-8.04) while $92.9 \%$ of that was HBeAg sero-negative. The HBV genotype distribution found was: A (59\%), D (21\%), and F (20\%). Coinfection with HCV (HBV HCV) was found to be $1.9 \%$, and with hepatitis D virus (HBV HDV) was found to be $3.8 \%$.

Only five treatment-naïve patients of the Northeastern Region ( $\mathrm{n}=84$ ) had mutations at positions that may be associated with viral resistance, as described in Table 2. No patient 
Table 2 Virological and resistance mutation profile of CHB-naïve patients to analog nucleos $(\mathrm{t})$ ides

\begin{tabular}{|c|c|c|c|c|c|c|c|c|c|c|c|}
\hline \multirow[t]{2}{*}{ Patient } & \multirow{2}{*}{$\begin{array}{l}\text { Age } \\
\text { (years) }\end{array}$} & \multirow[t]{2}{*}{ Gender } & \multirow{2}{*}{$\begin{array}{l}\text { Viral load } \\
\text { (log Ul/mL) }\end{array}$} & \multirow[t]{2}{*}{ Genotype } & \multicolumn{2}{|c|}{ Mutation } & \multirow{2}{*}{$\begin{array}{l}\mathrm{HBeAg} \\
\text { status }\end{array}$} & \multicolumn{4}{|c|}{ Resistance profile } \\
\hline & & & & & rtHBV & sHBV & & LAM & ADV & ETV & TDF \\
\hline $\mathrm{H}: 35 \mathrm{I}$ & 56 & $M$ & 3.72 & $\mathrm{Al}$ & S202I & & No reagent & $S$ & $S$ & $\mathrm{R}$ & $S$ \\
\hline $\mathrm{H}: 105$ & 62 & M & 8.6 & Al & Al94T & & No reagent & $S$ & $\mathrm{~S}$ & $S$ & $\mathrm{R}$ \\
\hline $\mathrm{H}: \mathrm{II7}$ & 48 & M & 2.21 & Al & M204I & QI29H & Reagent & $\mathrm{R}$ & $\mathrm{S}$ & 1 & $\mathrm{~S}$ \\
\hline $\mathrm{H}: 123$ & 27 & $M$ & 6.11 & $\mathrm{~F} 2$ & AI8IS & & Reagent & $\mathrm{R}$ & $\mathrm{R}$ & $S$ & $S$ \\
\hline $\mathrm{H}: 226$ & 30 & M & 8.3 & $\mathrm{~A} 2$ & $\begin{array}{l}\text { LI80M + } \\
\text { M204V }\end{array}$ & $1195 M$ & Reagent & $\mathrm{R}$ & $S$ & $\mathrm{R}$ & $S$ \\
\hline
\end{tabular}

Abbreviations: ADV, adefovir dipivoxil; CHB, chronic hepatitis B; ETV, entecavir; HBeAg, hepatitis B e antigen; HBV, hepatitis B virus; I, intermediate/reduced susceptibility; LAM, lamivudine; $R$, resistant; S, susceptible; TDF, tenofovir.

Table 3 Comparing the epidemiological characteristics of patients with resistance mutations and without resistance mutations in the HBV RT region

\begin{tabular}{|c|c|c|}
\hline Characteristics & $\begin{array}{l}\text { Group with } \\
\text { mutation }(n=5)\end{array}$ & $\begin{array}{l}\text { Group without } \\
\text { mutation }(n=79)\end{array}$ \\
\hline \multicolumn{3}{|l|}{ Genotype } \\
\hline Type A & 4 & 71 \\
\hline Type non-A & I & 8 \\
\hline \multicolumn{3}{|l|}{ Gender } \\
\hline Male & 4 & 36 \\
\hline Female & I & 38 \\
\hline \multicolumn{3}{|l|}{$\mathrm{HbeAg}$} \\
\hline Positive & 3 & 7 \\
\hline Negative & 2 & 60 \\
\hline \multicolumn{3}{|l|}{ Age } \\
\hline$\geq 40$ years & 3 & 44 \\
\hline$\leq 40$ years & 2 & 21 \\
\hline \multicolumn{3}{|l|}{ HBV DNA } \\
\hline$\geq \log 4$ & 2 & 10 \\
\hline$\leq \log 4$ & 3 & 62 \\
\hline \multicolumn{3}{|l|}{ ALT } \\
\hline$\leq \mathrm{RV}=4 \mathrm{I} \mathrm{IU} / \mathrm{mL}$ & 2 & 44 \\
\hline$\geq R V=4 \mid \mathrm{IU} / \mathrm{mL}$ & 3 & 26 \\
\hline
\end{tabular}

Note: There was no significant association at $P<0.05$.

Abbreviations: $\mathrm{HBeAg}$, hepatitis $B$ e antigen; $H B V$, hepatitis $B$ virus; $A L T$, alanine aminotransferase; RV, reference value; IU, international unit.

had the resistance mutation at FUNDHACRE $(n=105)$. The mutations were rtA194T, rtL180M + rtM204V, rtS202I, rtM204I, and rtA181S. In the pre $\mathrm{S} / \mathrm{S}$ region, there were sI195M and sQ129H.

No significant correlation between the group with mutation and the group without mutation was found in our sample described in Table 3.

\section{Discussion}

Resistance mutations to NA have been described in treatmentnaïve patients treated for $\mathrm{CHB}$, with clinical implications. It is important to track changes in primary and secondary resistance mutations in patients that have not yet been processed ${ }^{10}$ in order to monitor, optimize, and advocate the best treatment, achieving sustained virological response (SVR) and, consequently, reducing the progression of cirrhosis and the evolution to $\mathrm{HCC} .{ }^{15}$

In this study, the patients evaluated were from two reference centers for viral hepatitis in Brazil, one at the Northern Region, which has the highest prevalence rates for $\mathrm{CHB}$, and one at the Northeastern Region, which is considered to have a low prevalence of CHB. In both the reference centers, the naïve patients had an average age of $\sim 40$ years, mostly females, and had the serological marker $\mathrm{HBe} \mathrm{Ag}$ - mostly, demonstrating a global and Brazilian trend, of the prevalence of $\mathrm{CHB}$ patients with $\mathrm{HBeAg}-.{ }^{16-18}$ However, the patients in the Northeastern Region, compared to the ones from Northern Region, showed values above the reference value for ALT (38.7\% vs $28.3 \%$ ).

The circulating genotypes already described for Brazil are A, D, and F., ${ }^{4,20}$ Of them, the predominant is genotype A, as observed in the Northeastern Region with almost $90 \%$, followed by the genotypes F, D, and C. In the Northern Region, genotype A was also predominant, with almost $60 \%$, followed by the genotypes $\mathrm{D}$ and $\mathrm{F}$. And the proportion of genotype $\mathrm{F}$ is more common in the indigenous population in the Amazon region, compared with other Brazilian regions. ${ }^{21,22}$ Besides that genotype $\mathrm{F}$ is more frequent in the Amazon region, and coinfection with HBV HDV (delta) is also very common, with a found prevalence of $3.8 \%$, followed by coinfection with $\mathrm{HBV} \mathrm{HCV}$, with a prevalence of $1.8 \%$ in the patients studied. Regarding the frequencies of subgenotypes found in the Northeastern Region were A1 (71\%), A2 (4\%), C2, D2, and D3 (1\%), and F2 (6\%). The frequencies of subgenotypes found in the Northern Region were A1 (59\%), D1 (1\%), D2 (2.9\%), D3 (10.5\%), D4 (6.7\%), F1 (7.6\%), and F2 (12.4\%). The subgenotype A1 has been mostly identified in African population and its descendants. Subgenotype A2 is primarily found among Europeans. ${ }^{23,24}$ Genotype $\mathrm{C}$ is the most prevalent in Asia. In Brazil, due to the intense migration of people 
of Asian descent, genotype C2 was found. ${ }^{27,28}$ Genotype D is divided into four subgenotypes (D1, D2, D3, and D4) found in different continents. The genotype $\mathrm{F}$ is considered indigenous to the American continents, and four subgenotypes have been described, F1, F2, F3, and F4. In Latin America, genotype $\mathrm{F}$ is the most prevalent, with an exception of Brazil, where genotype A. ${ }^{26}$

The presence of resistance mutations in treatment-naïve patients has shown clinical significance due to the preexisting mutations, which need to be investigated and traced. In this study, we used direct sequencing of the HBV's DNA from the RT from the polymerase region to track resistance mutations to NA. In the Northern Region, there were no primary or secondary resistance mutations to NA. In some studies, in treatment-naïve patients, they were not found too. ${ }^{27,28}$ However, in patients in the Northeastern Region, mutations resistant to NA were found (5/84) corresponding to a prevalence of $6 \%$ of the samples. In several studies in the literature, most of them being held in the Asian population, the resistance mutation rates in naïve patients revolve $\sim 1 \%-20 \%{ }^{28-32,10}$ In Brazil, in a recently published study, ${ }^{33}$ with samples from various regions of Brazil, the resistance rate of mutations associated with NA was found to be $1.6 \%$ in naïve patients. Expanding the prevalence for the Northern and Northeastern regions, the prevalence of resistance mutations to NA was found to be $2.6 \%$.

One of the resistance mutations found in the Northeastern Region was rtA194T, which can be associated with resistance to TDF, which has shown in vitro reduced susceptibility to TDF when combined with the resistance mutations to LAM M204V and L180M. The clinical implication of the rtA194T mutation must be determined through long-term followup clinical studies. ${ }^{34,35}$ The $\mathrm{HBeAg}$ - patients may have an increased risk of selecting the rtA194T mutation, and therefore, antiviral resistance, so another alternative would be an indication of ETV as a first drug of choice. ${ }^{36}$

The other two mutations are associated with resistance to LAM rtL180M + rtM204V and rtS202I. The rtM204V mutation is considered a primary resistance mutation due to the susceptibility of HBV to LAM, and the rtL180M mutations are considered compensatory or secondary mutations, ${ }^{37}$ which can increase the viral replication fitness. ${ }^{38}$ The rtM204V mutation was the most common in studies of naïve patients, ${ }^{39,40}$ which is the resistance mutation associated with LAM. However, according to the Clinical Protocol of Therapeutic Guidelines for Chronic Hepatitis B, ${ }^{7}$ LAM is not indicated as a first-line choice because of its low genetic barrier and antiviral resistance rate that can reach $\sim 80 \%$ in 5 years of treatment. ${ }^{6,41}$ The first-line choices of antiviral treatment for treatment-naïve patients without cirrhosis are ETV and TDF, recommended by the Ministry of Health.

The resistance mutations $\mathrm{rtL} 180 \mathrm{M}+\mathrm{rtM} 204 \mathrm{~V}$ and rtS202I may be associated to the presence of mutations in the coding region of the HBsAg envelope region ( $\mathrm{S}$ of the HBV), as found in the patterns I195M, W196L, and G145R, indicating vaccine escape. Mutations in the polymerase region associated with LAM resistance can produce changes in the envelope region (S) and, as they are superimposed, it results in a reduction of antigenicity of the HBsAg protein. Another interesting point is that these patterns of mutations found in patients with resistance mutations to $\mathrm{NA}$ in the $\mathrm{S}$ region are more described for genotype A, compared to genotype D. In the literature, there are no mutations in the $\mathrm{S}$ region associated with the $\mathrm{rtA} 194 \mathrm{~T}$ resistance mutation, confirming the results found. ${ }^{42,43}$ The emergence of adefovir resistant mutant in patients with LAM resistance is more common than in treatment-naïve patients. Two major mutations of adefovir resistance are $\mathrm{rtN} 236 \mathrm{~T}$ and $\mathrm{rtA} 181 \mathrm{~V} / \mathrm{T}$, and in the current study we found the rtN236T mutation.

Comparing the patients with resistance mutations to NA and those without mutations, no clinical evidence was found. However, Zhang et $\mathrm{al}^{44}$ conducted a meta-analysis to apprise the incidence of natural resistance mutations in naïve chronic hepatitis B patients. They found genotype $\mathrm{CHBV}$ infection, male, and HBeAg negative patients had a slightly higher natural mutation rate when compared with genotype $\mathrm{B}$ and D HBV infection, female, and $\mathrm{HBeAg}$ positve patients. The ALT serum levels showed no influence on the emergence of antiviral resistance mutations. ${ }^{44}$ In Brazil, there are few studies that were conducted on survey resistance mutations to NA on naïve patients seeking clinical association. ${ }^{45-47}$ However, other studies should be conducted to track and trace the changes in the mutation profile, crossing with the epidemiological characteristics of the population, with a larger number of treatment-naïve patients with CHB.

In conclusion, it is important to track the resistance mutations genotypic to NA in naïve patients due to preexisting mutations in the RT region associated with antiviral treatment. The therapeutic efficacy of the antiviral treatment can be affected by many factors including infection with drugresistant viral strains. Since a treatment-naïve patient carries strain with resistance mutations, one must question if it is worthwhile to start the treatment with a drug for which that mutation produces resistance. This information, before the start of treatment, may contribute to clinical decision making, reducing therapeutic failure, and the risk of progression to cirrhosis and $\mathrm{HCC}$ for $\mathrm{CHB}$. 


\section{Abbreviations}

ADV, adefovir dipivoxil; ALT, alanine aminotransferase; $\mathrm{CHB}$, chronic hepatitis B; ETV, entecavir; HBeAg, hepatitis B e antigen; HBsAg, hepatitis B surface antigen; HBV, hepatitis $\mathrm{B}$ virus; $\mathrm{HCC}$, hepatocellular carcinoma; $\mathrm{HCV}$, hepatitis $\mathrm{C}$; LAM, lamivudine; NA, nucleoside/nucleotide analogs; PCR, polymerase chain reaction; PEG-IFN, pegylated interferon; RT region, reverse transcriptase region; TDF, tenofovir

\section{Acknowledgments}

The authors thank Silvana Paz, technician on the sequencing facility of the Program for Technological Development in Tools for Health (PDTIS), Fiocruz, the workers from LACENBA, LACEN-AC, and Fundação Hospitalar do Acre (Fundhacre). Funding support was provided by the National Counsel of Technological and Scientific Development (CNPq) process 478322/2012-7 and the Coordenação de Aperfeiçoamento de Pessoal de Nível Superior (CAPES) "Brasil sem Miséria" (BSM, Brazil without Misery) fellowship.

\section{Disclosure}

The authors report no conflicts of interest in this work.

\section{References}

1. Trépo C, Chan HL, Lok A. Hepatitis B virus infection. Lancet. 2014;384:2053-2063.

2. Ministério da Saúde, Departamento de DST, Aids e Hepatites Virais. Secretária de Vigilância em Saúde. Hepatites Virais no Brasil. Situações, Ações. Agenda 2011.

3. Pereira LM, Martelli CM, Merchán-Hamann E, et al. Population-based multicentric survey of hepatitis B infection and risk factor differences among three regions in Brazil. Am J Trop Med Hyg. 2009;81:240-247.

4. Mello FC, Souto FJ, Nabuco LC, et al. Hepatitis B virus genotypes circulating in Brazil: molecular characterization of genotype $\mathrm{F}$ isolates. BMC Microbiol. 2007;7:103.

5. Di Bisceglie AM. Hepatitis B and hepatocellular carcinoma. Hepatology. 2009;49:S56-S60.

6. Lok AS, McMahon BJ. Chronic hepatitis B: update 2009. Hepatology. 2009;50:661-662.

7. Ministério da Saúde. Protocolo Clínico e Diretrizes Terapêuticas para o Tratamento da Hepatite Viral Crônica B e Coinfecções. In: Secretaria de Vigilância em Saúde - Departamento de DST AeHV, editor. Programa Nacional para a Prevenção e o Controle das Hepatites Virais. 2011.

8. Lok AS, Zoulim F, Locarnini S, et al. Antiviral drug-resistant HBV: standardization of nomenclature and assays and recommendations for management. Hepatology. 2007;46:254-265.

9. Jardi R, Rodriguez-Frias F, Schaper M, et al. Hepatitis B virus polymerase variants associated with entecavir drug resistance in treatmentnaïve patients. J Viral Hepat. 2007;14:835-840.

10. Nguyen MH, Garcia RT, Trinh HN, et al. Prevalence of hepatitis B virus DNA polymerase mutations in treatment-naïve patients with chronic hepatitis B. Aliment Pharmacol Ther. 2009;30:1150-1158.

11. Norder H, Couroucé AM, Coursaget P, et al. Genetic diversity of hepatitis B virus strains derived worldwide: genotypes, subgenotypes, and HBsAg subtypes. Intervirology. 2004;47:289-309.

12. Deterding K, Constantinescu I, Nedelcu FD, et al. Prevalence of HBV genotypes in Central and Eastern Europe. J Med Virol. 2008;80(10):1707-1711.
13. McMahon BJ, Dentinger CM, Bruden D, et al. Antibody levels and protection after hepatitis B vaccine: results of a 22 -year follow-up study and response to a booster dose. J Infect Dis. 2009;200:1390-1396.

14. Krekulova L, Rehak V, Da Silva Filho HP, Zavoral M, Riley LW. Genotypic distribution of hepatitis B virus in the Czech Republic: a possible association with modes of transmission and clinical outcome. Eur $J$ Gastroenterol Hepatol. 2003;15:1183-1188.

15. Chen CJ, Yang HI, Su J, et al. Risk of hepatocellular carcinoma across a biological gradient of serum hepatitis B virus DNA level. JAMA. 2006;295:65-73.

16. Hadziyannis SJ, Vassilopoulos D. Hepatitis B e antigen-negative chronic hepatitis B. Hepatology. 2001;34(4 Pt 1):617-624.

17. Galizzi FJ, Teixeira R, Fonseca JC, Souto FJ. Clinical profile of hepatitis $B$ virus chronic infection in patients of Brazilian liver reference units. Hepatol Int. 2010;4(2):511-515.

18. Chachá SG, Ferreira SC, Costa TV, et al. Clinical, demographic and epidemiological characteristics of patients with hepatitis B followed at a university hospital in southeastern Brazil: predominance of $\mathrm{HBeAg}$ negative cases. Rev Soc Bras Med Trop. 2011;44(1):13-17.

19. Sitnik R, Pinho JR, Bertolini DA, Bernardini AP, Da Silva LC, Carrilho FJ. Hepatitis B virus genotypes and precore and core mutants in Brazilian patients. J Clin Microbiol. 2004;42:2455-2460.

20. de Oliveira CM, Farias IP, Ferraz da Fonseca JC, Brasil LM, de Souza $\mathrm{R}$, Astolfi-Filho S. Phylogeny and molecular genetic parameters of different stages of hepatitis B virus infection in patients from the Brazilian Amazon. Arch Virol. 2008;153:823-830.

21. Viana S, Parana R, Moreira RC, Compri AP, Macedo V. High prevalence of hepatitis $\mathrm{B}$ virus and hepatitis D virus in the western Brazilian Amazon. Am J Trop Med Hyg. 2005;73:808-814.

22. Santos AO, Alvarado-Mora MV, Botelho L, et al. Characterization of hepatitis B virus (HBV) genotypes in patients from Rondonia, Brazil. Virol J. 2010;7:315.

23. Hannoun C, Soderstrom A, Norkrans G, Lindh M. Phylogeny of African complete genomes reveals a West African genotype A subtype of hepatitis B virus and relatedness between Somali and Asian A1 sequences. J Gen Virol. 2005;86:2163-2167.

24. Kramvis A, Kew MC. Molecular characterization of subgenotype A1 (subgroup Aa) of hepatitis B virus. Hepatol Res. 2007;37:S27-S32.

25. Alvarado-Mora MV, Santana RA, Sitnik R, et al. Full-length genomic sequence of hepatitis $\mathrm{B}$ virus genotype $\mathrm{C} 2$ isolated from a native Brazilian patient. Mem Inst Oswaldo Cruz. 2011;106:495-498.

26. Alvarado-Mora MV, Pinho JR. Distribution of HBV genotypes in Latin America. Antivir Ther. 2013;18:459-465.

27. Xu J, Wu B, Wang J-H, et al. Pre-existing mutations in reverse transcriptase of hepatitis B virus in treatment-naïve Chinese patients with chronic hepatitis B. PLoS One. 2015;10(3):e0117429.

28. Liu BM, Li T, Xu J, et al. Characterization of potential antiviral resistance mutations in hepatitis B virus reverse transcriptase sequences in treatment-naïve Chinese patients. Antiviral Res. 2010;85(3): 512-519.

29. Pollicino T, Isgrò G, Di Stefano R, et al. Variability of reverse transcriptase and overlapping $\mathrm{S}$ gene in hepatitis $\mathrm{B}$ virus isolates from untreated and lamivudine-resistant chronic hepatitis B patients. Antivir Ther. 2209; 14:649-654.

30. Tauseef I, Iqbal F, Rehman W, Ali M, Qureshi JA, Aslam MA. A PCRRFLP based protocol for the detection of hepatitis $B$ virus variants in some lamivudine-untreated chronic hepatitis B virus carriers in Pakistan. Pak J Pharm Sci. 2012;25:349-352.

31. Tan YW, Ge GH, Zhao W, et al. YMDD motif mutations in chronic hepatitis B antiviral treatment naïve patients: a multi-center study. Braz J Infect Dis. 2012;16:250-255.

32. Selabe SG, Lukhwareni A, Song E, Leeuw YG, Burnett RJ, Mphahlele MJ. Mutations associated with lamivudine-resistance in therapynaïve hepatitis B virus (HBV) infected patients with and without HIV co-infection: implications for antiretroviral therapy in HBV and HIV co-infected South African patients. J Med Virol. 2007;79: $1650-1654$. 
33. Gomes-Gouvêa MS, Ferreira AC, Teixeira R, et al. HBV carrying drugresistance mutations in chronically infected treatment-naïve patients. Antivir Ther. 2015;20:387-395.

34. Funk ML, Rosenberg DM, Lok AS. World-wide epidemiology of HBeAg-negative chronic hepatitis B and associated precore and core promoter variants. J Viral Hepat. 2002;9:52-61.

35. Tenney DJ, Rose RE, Baldick CJ, et al. Long-term monitoring shows hepatitis B virus resistance to entecavir in nucleoside-naïve patients is rare through 5 years of therapy. Hepatology. 2009;49:1503-1514.

36. Amini-Bavil-Olyaee S, Herbers U, Sheldon J, Luedde T, Trautwein C, Tacke F. The rtA194T polymerase mutation impacts viral replication and susceptibility to tenofovir in hepatitis B e antigen-positive and hepatitis B e antigen-negative hepatitis B virus strains. Hepatology. 2009;49:1158-1165.

37. Hoofnagle JH, Doo E, Liang TJ, Fleischer R, Lok AS. Management of hepatitis B: summary of a clinical research workshop. Hepatology. 2007;45:1056-1075.

38. Zoulim F, Locarnini S. Hepatitis B virus resistance to nucleos(t)ide analogues. Gastroenterology. 2009;137:1593-1608.

39. Feeney E, Fanning LJ, Horgan M. Baseline genotypic resistance in untreated hepatitis B virus infection. Gastroenterology. 2007;132:35A

40. Fung J, Lai CL, Fong DY, Yuen JC, Wong DK, Yuen MF. Correlation of liver biochemistry with liver stiffness in chronic hepatitis B and developmen of a predictive model for liver fibrosis. Liver Int. 2008;28:1408-1416.
41. Shaw T, Bartholomeusz A, Locarnini S. HBV drug resistance: mechanisms, detection and interpretation. J Hepatol. 2006;44: 593-606.

42. Torresi J. The virological and clinical significance of mutations in the overlapping envelope and polymerase genes of hepatitis B virus. J Clin Virol. 2002;25:97-106.

43. Sheldon J, Soriano V. Hepatitis B virus escape mutants induced by antiviral therapy. J Antimicrob Chemother. 2008;61:766-768.

44. Zhang Q, Liao Y, Cai B, et al. Incidence of natural resistance mutations in naïve chronic hepatitis B patients: a systematic review and metaanalysis. J Gastroenterol Hepatol. 2015;30:252-261.

45. Bottechia M, Souto FJ, Kycia MR, et al. Hepatitis B virus genotypes and resistance mutations in patients under long term lamivudine therapy: characterization of genotype $\mathrm{G}$ in Brazil. BMC Microbiol. 2008;8:11.

46. Da Silva LC, Pinho JR, Da Fonseca LE, Carrilho FJ. Efficacy and tolerability of long-term therapy using high lamivudine doses for the treatment of chronic hepatitis B. J Gastroenterol. 2001;36(7): 476-485.

47. Haddad R, Martinelli Ade L, Uyemura SA, Yokosawa J. Hepatitis B virus genotyping among chronic hepatitis B patients with resistance to treatment with lamivudine in the City of Ribeirão Preto, State of São Paulo. Rev Soc Bras Med Trop. 2010;43(3):224-228.
Infection and Drug Resistance

\section{Publish your work in this journal}

Infection and Drug Resistance is an international, peer-reviewed openaccess journal that focuses on the optimal treatment of infection (bacterial, fungal and viral) and the development and institution of preventive strategies to minimize the development and spread of resistance. The journal is specifically concerned with the epidemiology of antibiotic

\section{Dovepress}

resistance and the mechanisms of resistance development and diffusion in both hospitals and the community. The manuscript management system is completely online and includes a very quick and fair peerreview system, which is all easy to use. Visit http://www.dovepress.com/ testimonials.php to read real quotes from published authors. 